\title{
The Potential of Virtual Global Mobility (VGM): Implications for practice and future research
}

\begin{abstract}
Purpose - In recent years global organizations have been forced to adopt technology-driven virtual solutions involving faster, less costly and more effective ways to work worldwide. One potential outcome may be through Virtual Global Mobility (VGM), defined as the replacement of personal physical international interactions for work purposes with electronic personal online interactions. The purpose of this article is to discuss the potential of VGM and explore to what extent it can replace or complement physical global work assignments.

Design/methodology/approach - We aim to raise a discussion about the concept of VGM and elaborate on its potential to replace physical mobility.

Findings - Representing a change of trend, we argue that long-term corporate expatriates could become necessary core players in VGM activities while the increase of the number of global travellers may be halted or reversed.

Originality/value - Even though we have witnessed a massive trend of increasing physical global mobility there is also a counter-trend: instead of moving people to their work we see organizations moving work to people. Given this development, as one of the first articles to do so, we chart the suitability of VGM to fulfil organizational objectives.
\end{abstract}

Keywords: Virtual Global Mobility (VGM); Global virtual work; Expatriates; Global travellers; Global work assignment purposes 


\section{The Potential of Virtual Global Mobility (VGM): Implications for practice and future research}

\section{Introduction}

The COVID-19 pandemic has caused an unprecedented global crisis and has resulted in an unexpected, and sudden disruption to billions of employees around the world (Kniffin et al., 2021). Global organizations were forced to change their operations basically overnight and many employees were required to work from home. Pressed to resolve communication challenges, organizations adopted technology-driven virtual solutions (Nell et al., 2020) and have increasingly transitioned traditional jobs into more fluid work (Boudreau, 2020). While this was first perceived as a substantial burden there could also be advantages connected to adopting a virtual style of working. In particular, faster, less costly and more effective ways to work worldwide can create competitive strategic advantages that will enable global organizations to emerge from the pandemic even stronger. One potential outcome of the recent pandemic may be what we refer to as Virtual Global Mobility (VGM), which is defined as the replacement of personal physical international interactions for work purposes with electronic personal online international interactions (Selmer, 2021).

The purpose of this article is to discuss the potential of VGM and assess to what extent it can replace or complement physical global work assignments. We first elaborate on the nature of international online work and how this can establish certain preconditions for VGM. We then discuss the implementation of VGM and analyse to what extent and how VGM can substitute physical relocation for different types of expatriates. Following this, we outline managerial implications and directions for future research. 


\section{Virtual work and its consequences for VGM}

In this article, we have described VGM as moving work to people across national borders instead of moving people to their work. Here the focus is specifically on the technology mediated work of white collar workers that has traditionally been performed by expatriates. In that regard, three classical, yet still relevant, purposes for global work assignments are to fill positions, to develop organizations and to develop managers (Caligiuri and Bonache, 2016; Edström and Galbraith, 1977). Other scholars have further developed these three purposes into 1) teaching business applications (global employees as knowledge senders), 2) developing organizational applications (global employees as contributing to organizational maintenance and growth), and 3) learning by doing (global employees as knowledge recipients) (Hocking et al., 2004). To the extent that VGM work refers to work traditionally done by expatriates, it can be conceived as 'teaching business applications', 'developing organization applications' and 'learning by doing' - all of which are undertaken across physical distance by the use of technology mediated communication.

In comparison to face-to-face work carried out by expatriates, the use of virtual interactions will have both advantages and disadvantages for the individual and for the organization. The main advantages are related to cost savings and flexibility for the organization as well as the possibility for the individual to stay in one's home community (Jimenez et al., 2017). Disadvantages, include weaker interpersonal relationships that could, for example, result in lower levels of trust between the virtual expatriate and the local staff (Breuer et al., 2020) as well as the need to overcome time zone gaps that could lead to extended working days and the consequent impairment to work life balance (Nurmi, 2011). Some of the disadvantages can be alleviated by managerial and organizational initiatives. For example, researchers have argued that organizations can use a 'follow the sun' principle to deal with time zone issues (Colazo and Fang 2009), and social disengagement can be somewhat improved by organizing physical meetings at strategically important points in 
time (Richter et al, 2021). Hence, it can generally be argued that individuals and organizations can learn to deal with most issues connected to virtual work so that they do not come to represent serious problems to productivity and wellbeing (Lauring et al. forthcoming; Maznevski and Chudoba, 2000).

Some challenges that are connected to the context of virtual work are particularly relevant to VGM. For example, the role of adjustment to working across cultural boundaries could be affected by working at a distance. Here, research has shown both advantages and disadvantages connected to virtual work. For example, on the one hand, intercultural integration can be challenged by online collaboration due to a general withdrawal from social involvement (cf. Konradt et al., 2003; Mortensen and Hinds, 2001). On the other hand, however, social categorization may not play the same negative role in virtual interpersonal interactions as compared to collocated interpersonal settings (Han and Beyerlein, 2016). This can be related to the findings by Kirkman et al. (2002) who demonstrate that remote work can actually reduce process losses associated with stereotyping, politics, and power struggles compared to the physical workplace. Similarly, Stahl et al. (2010) found that cultural diversity was, to a lesser extent, the cause for conflict in dispersed work groups. Hence, there are both positive and negative consequences of VGM in relation to intercultural activities that include expatriates' teaching of business applications, development of organizational applications and learning by doing.

\section{Implementation of VGM}

So far we have argued that virtual global work is complex and multifaceted. In this section, we consider two aspects of global work that have implications for the role of VGM. First, we propose that VGM will influence various types of global work assignments differently. Second, we 
contend that the purpose of a global work assignment will determine whether VGM can be a suitable replacement for actual, physical global mobility.

\section{Implications of VGM for the evolution of global work assignments}

Employees occupying global work assignments can be categorized in various ways (e.g., Jooss et al., 2021; Shaffer et al., 2012; McNulty \& Brewster, 2017a). We build on the classification by Shaffer et al. (2012) who distinguish between expatriates and global travellers. The first category comprises Corporate Expatriates and Self-Initiated Expatriates while the second group includes Short-Term Assignees, Flexpatriates and International Business Travelers. Because international commuters have generally been subsumed within the flexpatriate category (e.g., Mayerhofer et al., 2004b), Shaffer and colleagues did not view it as a separate type of global work assignment. However, with increased remote work, international commuters may be an important phenomenon. Therefore, we follow Jooss et al. (2021) to include this as a separate category.

\section{Expatriates:}

Corporate expatriates can be defined as employees who are assigned by their business organization to another country, usually for several years, to undertake a specific task or achieve an organizational goal (Harrison et al., 2004). Applying VGM, parent country national corporate expatriates in the host country location could serve a crucial bridging role between headquarters staff and host country national employees. However, it is possible that this bridging role is limited when it comes to the transfer of tacit knowledge, which likely requires face-to-face interaction (e.g., Reiche, 2011).

Self-initiated expatriates are individuals who initiate and usually pay for their own expatriation. Not being transferred by organizations, they move to a country of their choice for 
work purposes, often with no definite time frame in mind (Cerdin and Selmer, 2014; Doherty et al., 2011; Tharenou and Caulfield, 2010). The use of foreign self-initiated expatriates as leaders and important decision makers in host locations may, however, diminish with VGM. They may also be less familiar with corporate policy and therefore be less versatile than parent country national corporate expatriates in charge of foreign subsidiaries.

Global travellers:

The trend of using global travellers may also change as a result of VGM, but there may be differentiations between the types of global traveller. Short-term assignees are employees on international assignments longer than a business trip but shorter than a typical corporate expatriate assignment, usually 3-12 months, to one or a few countries, typically without family (Mayerhofer et al., 2004a). Short-term assignees, who typically undertake longer assignments than the other types of global travellers, may be most in need of a physical presence at the foreign host location and, consequently, may be less likely to be replaced by VGM. Flexpatriates and international business travellers differ from short-term assignees in that they generally undertake consecutive multiple country assignments. Flexpatriates are employees who undertake brief international assignments, typically of 1-2 months, to multiple foreign locations, usually without accompanying family (Mayerhofer et al., 2004a) and international business travellers are employees who make frequent international business visits to foreign markets, units, projects, etc., generally for periods of 1-3 weeks to multiple countries without accompanying family (Welch et al., 2007). International business travellers, who usually just need to stay for very short periods of time at the foreign location, may be more easily replaced by VGM. However, the replacement of flexpatriates by VGM may be somewhere in-between short-term assignees and international business travellers. International commuters, who reside in one country and work in another country, generally 
commute to just one foreign location on a daily, weekly, or another time interval basis (Mäkelä et al., 2017). With their mobility generally restricted to one country and the burden of their commuting times and costs, commuters may see VGM as a viable alternative to physical mobility. Given the rise of hybrid working patterns (Shankar, 2020) this points to a replacement of some but not necessarily all travel activity.

Drawing on the collective expertise and experience of the entire organization of a multinational corporation (MNC), in the parent country as well as worldwide, the individuals involved in VGM activities may not be identical to the group of staff who would have worked abroad before the pandemic. The VGM implications for global work assignments are summarized in Table 1.

*** Insert Table 1 about here ***

Although the discussion so far has implied that global workers' physical global mobility in contemporary MNCs takes place only unidirectionally, from the parent country to the host country location(s), this is seldom the case in practice. Mobility may occur in all directions. For example, expatriates embark on lateral, consecutive moves as global careerists (Dickmann and Andresen, 2018; Näsholm, 2014), many MNCs apply reverse transfers of foreign subsidiary employees as inpatriates (Froese et al., 2016; Moeller and Reiche, 2017; Reiche, 2011) and third country nationals from one foreign subsidiary may transfer to another subsidiary (Harzing et al., 2016). Similarly, global travellers may also originate from foreign regional headquarters or even single subsidiaries abroad (e.g. Welch et al., 2007). While VGM is also amenable to the multi-dimensional movement of global work, it may not always be a suitable replacement for physical mobility. In the next 
section, we consider how the purpose of the global work assignment may influence the applicability of VGM.

\section{Global work assignment purposes and VGM}

As mentioned, deciding to replace personal physical international interactions with VGM could depend on the purpose of the global work assignment in the forms of teaching business applications (global employees as knowledge senders), organization applications (global employees as contributing to organizational maintenance and growth), and learning by doing (global employees as knowledge recipients) (Hocking et al., 2004).

Teaching business applications:

This first category, teaching business applications, is generally suitable for VGM. Many universities have, in some form or another, converted to on-line teaching and found that although virtual teaching may be less effective than face-to-face interactions, it can still produce acceptable results (Charoensukmongkol and Phungsoonthorn, 2020; George, 2020; Klein et al., 2021). However, the adoption of VGM may depend on the type of business application involved. Managerial know-how applications involve a transfer of managerial expertise, which is often a temporary need when managing the start-up phase of an international business (Gong, 2003; McNulty and Brewster, 2017b). Hence, VGM seems suitable as an alternative to international business travellers and other short-term assignments. Professional know-how applications concern the transfer of specialized technical know-how that represents a distinctive competency of firms; specialist global employees typically make up for a shortage or absence of such know-how at the host location (e.g., Chang et al., 2012). VGM seems to be a suitable replacement for assigning these specialist employees. Professional know-how training is applied through the transfer of global 
employees' experience-based knowledge and skills to others at the host location. This can be accomplished through formal instruction but also by teaching strategically valuable tacit knowledge to either fellow expatriates or local nationals (Selmer, 2004; Collings and Isichei, 2017). In this case, VGM may be suitable for formal instruction but less useful for the transfer of tacit knowledge, which may be better achieved by assigned corporate expatriates. Technology innovation transfer is associated with the relocation of newly developed technology incorporating both product and process-related knowledge; it is based on a process of replication throughout a firm, often by staff transfers (e.g., Kim et al., forthcoming). VGM may again be suitable in such situations but should, most likely, be complemented with transfers of specialist global employees. Corporate image promotions and external relations are usually pursued through external business relations and marketing activities, which may take place during the initial internationalization period or else on an ongoing basis (e.g., Harzing et al., 2016). Although VGM seems a suitable tool for promoting the corporate image, it may be less useful in establishing business relationships with external parties. In this latter case, a physical presence at the foreign location may be more appropriate.

Organization applications:

For the second purpose, organization applications, VGM may only be partly suitable. As with business applications, there are various organization applications that may differ in terms of the extent to which VGM is a viable alternative. The first type of organization application is coordination and networking, which can be achieved through personal inter-unit networks, mainly through long-term corporate or self-initiated expatriates (Stoermer et al., 2021). In particular, parent-country national expatriates can be crucial bridges between headquarters staff and host country nationals (Reiche et al., 2009). Hence, to achieve this objective, VGM may be less suitable. Other organization applications are culture transfer and socialization, which are important tasks, 
especially for parent country national expatriates and the socialization of subsidiary staff that is achieved over time (Lee et al., 2021). Although expatriates in situ may most efficiently attain this objective, virtual interactions may also be effective, making VGM partly suitable in this case. Policy transfer and control involve bureaucratic control in MNCs, either by centralization through a more direct headquarters control over subsidiaries or more indirectly through introducing policies and procedures (Lee et al., 2021). While VGM may have a role to play by transferring information about the details of bureaucratic control, the effective application may be best ensured through physical presence of an expatriate at the host location or through frequent visits by international business travellers. Finally, best practice systems transfer is a strategic practice for the firm to apply its own specific ways of information processing and other functions, enabling it to efficiently and consistently achieve global economies-of-scale (Belderbos and Heijltjes, 2005). This often occurs through the assignment of experts who facilitate organizational learning (Renshaw et al., 2021). Similarly, while VGM may be used to transfer information about such strategic practices, their application may require the attendance of a corporate expatriate at the foreign subsidiary.

Learning by doing applications:

For this third category of global assignment purposes, learning by doing, VGM may be less suitable since the intention is to give global employees international experience. In particular, this objective may require the physical presence of expatriates as well as global travellers in the host environment. After visits to other countries or after repatriation, global employees with experience in a certain host country could apply suitable teaching objectives through VGM more effectively than other methods (Froese, Stoermer, Reiche and Klar, 2021). The two objectives in this category, international business and professional experience as well as global company perspective reflect the two previous categories about business and organization applications. Although global 
employees may learn some aspects through virtual interactions with local representatives, it will not be equivalent to a physical presence at the foreign host location. Considering the local non-work context in which business operations are embedded, it may be especially important to have global workers on the ground. In the following section, we will discuss the potential consequences of VGM in terms of implications for practice and future research.

\section{Discussion: Implications for practice and research}

Our analysis has so far revealed great promise for VGM. Although considerable research has been devoted to VGM in the context of global virtual teams (e.g., Jimenez, et al., 2017), it has received scant attention relative to alternative global work roles. In relation to managerial practices, implementing VGM may involve direct and more distal replacement effects as well as shorter- and longer-term effects. For instance, reducing assignments for teaching business applications or organizational maintenance might trigger more local talent investment and a higher willingness to 'trust' locals to undertake certain activities and to fill certain control functions. So, while this might trigger more VGM work initially, it might mean a shift towards fewer global workers (i.e. more locals filling these roles).

Our discussion above has shown that the organizational effects of VGM may be farreaching. VGM is likely to substantially affect international HR configurations (Dickmann and Müller-Camen, 2006; Farndale et al., 2015) in that the very structures and global strategies might need to be adjusted to account for the new ways of doing international work. For instance, more VGM may affect the power that the head office wields - local operating units may enjoy more devolved autonomy and task authority - the culture and control mechanisms in organisations and with it the degree of trust and cohesion (cf. Bartlett and Ghoshal, 1998; Lee et al., 2021). In terms of human resource policies and practices, talent sourcing, local and global talent development 
approaches and global career patterns are likely to be modified to take account of the new ways of global competition.

Individuals working on global challenges will also be substantially affected. Not only will the physical mobility patterns have been modified in their organizations, the required knowledge, skills and abilities to conduct VGM successfully are substantially different as explored above. Given that some of the success factors of global virtual work include early face-to-face meetings to foster trust, shared group norms and respect (Jimenez et al., 2017; Maznevski and Chudoba, 2000) and that not all business travel or short-term assignments will cease, hybrid forms of global work will continue to exist. Thus, individuals will continue to physically cross national borders for work and will continue to have to acquire 'global business acumen' - only now it may consist of a broader set of global capabilities. Pre-COVID-19, the negative effects of global mobility received wide attention, including working in hostile environments (Bader et al., 2021), or discussing issues such as willingness and capability for global mobility (Froese et al., 2013). A world of work with a large share of VGM still needs to explore issues of individual willingness, capability, VGM effects and how to cope with these.

\section{Future research directions}

Accordingly, to implement, support and maintain VGM in global organizations, exploiting the competitive strategic advantages of global virtual work, training and mentoring, staffing and recruitment and organizational control are all important interventions and support functions. A future research stream examining such interventions to assist VGM would be essential for the future. Another issue involves the health, wellbeing and work-life balance of the individuals involved (e.g., Anderson and Kelliher, 2020; Escudero-Castillo et al., 2021; Raj and Bajaj, 2021). These concerns may also have relevance for VGM and constitute another stream of worthwhile 
future research. Finally, although MNCs have been the main focus of this paper, other types of organizations may also implement VGM. Academic institutions, international sports organizations, performing arts institutions, organizations within international health and aid work as well as religious institutions, etc. are examples of global organizations that, during the current pandemic situation, have applied some form of virtual work and may continue to do so in the future. Hence, another stream of future research may include how such organizations can make use of VGM.

The first stream of proposed future research concerns organizational measures to implement, support and maintain VGM. It would be essential to investigate different methods for training, mentoring and coaching individuals involved in and otherwise affected by VGM. Associated with that is the need to explore the nature and type of role transitions that individuals engaging in VGM experience and to find out if and how VGM role transitions differ from other forms of global work. Related to that would be the mapping and in-depth analysis of the temporal and dynamic interface between VGM and physical global mobility. In terms of staffing and recruitment, it would be important to know more about (potential) employees. Therefore, studying cultural, generational, and functional differences in employee preferences and capacities for VGM would be crucial. Regarding organizational control, it would be essential to examine the creation and character of possible organizational risks by applying VGM. For example, such risks could include less cultural cohesion within an MNC and loss of control and coordination in host-country locations.

The second suggested stream of valuable future research includes health, wellbeing and work-life balance and VGM. While the wellbeing impact of travelling less might see some positive development (cf. Mäkelä and Kinnunen 2018) it is clear that working from home may trigger many work-live balance and boundary conflicts (Putri and Amran, 2021; Hjálmsdóttir and Bjarnadóttir, 2021). It would be important to explore short-term effects, such as outcomes of the 'always-at-work syndrome' since they may cover a whole spectrum of detrimental effects of VGM. Likewise, it 
would also be vital to investigate such effects in the long term. Employee health concerns of being involved in VGM activities, whether real or imagined, would be a prime option to uncover.

The third proposed stream of future research about VGM concerns global organizations other than MNCs. The list of such organizations is long and the specific topics for suitable investigation may overlap with what has been mentioned regarding the above proposed two research streams. Here, a few distinct global organizations such as academic, performing arts and religious institutions can be mentioned. For universities, forced to suddenly embark on online teaching (e.g., Peimani and Kamalipour, 2021; Skulmowski and Rey, 2020), knowledge exchange (teaching and research) is typically not limited to any organizational context or circumstances. For example science and humanities concern knowledge of a more general character. Hence, it would be important to investigate if and how universities can make use of the best and most prominent academic teachers in the world and the resultant consequences for their current academic staff. Needless to say, research is already disseminated through a globalized electronic product, very much consistent with the concept of VGM. In addition, institutions of the performing arts have long tried various ways to share their performances electronically (e.g., Reichl et al., 2016). For example, opera houses have resorted to disseminating their performances electronically through video streaming, through their own or other (international) platforms. It would be fascinating to explore the wider and long-term consequences of such video opera versions to performers as well as to opera houses featuring them. In a similar way, many religious institutions have turned to electronic output (e.g., Golan and Martini, 2019). For example, Catholic Mass is now transmitted from the most renowned locations throughout the world, and most likely also from the parish church (e.g., Parish, 2020; Przywara et al., 2021). Hence, it would also be of interest to examine the general outcomes of such a development for believers, clergy and the church alike. 


\section{Conclusions}

Since World War II, we have witnessed a massive trend of increasing physical global mobility where individuals - be they expatriates or global travellers - have crossed international borders to conduct work. We are now observing the emergence of a counter-trend: instead of moving people to their work we often see work moving to people. Our article has explored some of the advantages and disadvantages of such global virtual work. Given the various purposes of global work we charted the suitability of VGM to fulfil these organizational objectives. But, as often in life, there are a range of intended and unintended consequences of change. On a broad organizational level, changes in global human resource configurations, power, communication and cultural effects are highly likely and will have to be assessed and carefully managed by global organizations (cf. Lee et al., 2021). In addition, reshaping the world of global work has many other effects and opportunities. Moving work to people through VGM may allow individuals to choose how much travel they want to undertake and where they want to live and work.

This raises the question: is the persistent change to more virtual work just a temporary phenomenon induced by the COVID-19 pandemic or is VGM here to stay? Based on the analysis above, we contend that VGM-related developments represent a change of trend. That means that long-term corporate expatriates could become necessary core players in VGM activities. In turn, the increase of the number of global travellers may be halted or reversed since their teaching objectives will be partly attained by VGM activities. It is also noteworthy that moving work to people instead of people to work through VGM does not necessarily change any business goals. However, it changes the way that global organizations pursue these goals and it may have profound changes in working patterns, talent development investment and recipients, as well as possible changes in organizational power structures over time. We are also convinced that VGM activities will grow and further develop due to a continued rapid development of communication and coordination 
technologies. VGM will likely also become increasingly attractive to more industries and larger international business segments because it may become increasingly cost-efficient and could even generate revenues by creating new business opportunities. 


\section{References}

Anderson, D. and Kelliher, C. (2020), "Enforced remote working and the work-life interface during lockdown", Gender in Management, Vol. 35 No. 7, pp. 677-683.

Bartlett, C.A. and Ghoshal, S. (1998), "Beyond strategic planning to organisation learning: lifeblood of the individualized corporation”, Planning Review, Vol. 26 No. 1, pp. 34-39.

Belderbos, R.A. and Heijltjes, M.G. (2005), “The determinants of expatriate staffing by Japanese multinationals in Asia: Control, learning, and vertical integration", Journal of International Business Studies, Vol. 36 No. 3, pp. 341-354.

Boudreau, J. W. (2020), “Jobs are melting into fluid work”, USC Marschall School of Business, Center for Effective Organizations, https://ceo.usc.edu/2020/09/29/jobs-are-melting-jobs-into-fluidwork/, accessed September 27, 2021.

Bowen, T. and Pennaforte, A. (2017), “The impact of digital communication technologies \& new remote-working cultures on the socialization and work-readiness of individuals in WIL programs", in Bowen, T. \& Drysdale M. T. B. (Eds.), Work-Integrated Learning in the 21st Century: Global Perspectives on the Future, Emerald Publishing Limited, Bingley, pp. 99-112.

Breuer, C., J. Hüffmeier and G. Hertel (2020), "Does trust matter more in virtual teams? A metaanalysis of trust and team effectiveness considering virtuality and documentation as moderators", Human Relations, Vol. 71, No (1), pp. 3-34.

Caligiuri, P. and Bonache, J. (2016), "Evolving and enduring challenges in global mobility", Journal of World Business, Vol. 51 No. 1, pp. 127-141.

Cerdin, J. L. and Selmer, J. (2014), “Who is a self-initiated expatriate? Towards conceptual clarity of a common notion”, International Journal of Human Resource Management, Vol. 25 No. 9, pp. $1281-1301$. 
Chang, Y.-Y., Gong, Y. and Peng, M.W. (2012), "Expatriate knowledge transfer, subsidiary absorptive capacity, and subsidiary performance", Academy of Management Journal, Vol. 55 No. 4, pp. 927-948.

Charoensukmongkol, P. and Phungsoonthorn, T. (2020), "The effectiveness of supervisor support in lessening perceived uncertainties and emotional exhaustion of university employees during the COVID-19 crisis: the constraining role of organizational intransigence", Journal of General Psychology, 1-20.

Colazo, J. and Y. Fang (2009), "Impact of license choice on open source software development activity", Journal of the Association for Information Systems, Vol. 60, No (11), pp. 997-1011. Collings, D. and Isichei, M. (2017). "Global talent management: what does it mean for expatriates?", in McNulty, Y. and Selmer, J. (Eds), The Research Handbook of Expatriates, Edward Elgar, London, pp. 148-159.

Dickmann, M. and Andresen, M. (2018), “Managing global careerists: individual, organizational and societal needs", in Dickmann, M., Suutari, V., and Wurtz, O. (Eds.), The Management of Global Careers, Palgrave Macmillan, Cham., pp.149-181.

Dickmann, M. and Müller-Camen, M. (2006), “A typology of international human resource management strategies and processes. International Journal of Human Resource Management, Vol. 17 No. 4, pp. 580-601.

Doherty, N., Dickmann, M. and Mills, T. (2011), "Exploring the motives of company-backed and self-initiated expatriates”, International Journal of Human Resource Management, Vol. 22 No. 3, pp. 595-611.

Edström, A. and Galbraith, J. R. (1977), “Transfer of managers as a coordination and control strategy in multinational organizations", Administrative Science Quarterly, Vol. 22 No. 2, pp. 248263. 
Escudero-Castillo, I., Mato-Díaz, F. and Rodriguez-Alvarez, A. (2021), "Furloughs, teleworking and other work situations during the COVID-19 lockdown: impact on mental well-being”, International Journal of Environmental Research and Public Health, Vol. 18 No. 6, pp. 2898. Farndale, E., Biron, M., Briscoe, D.R. and Raghuram, S. (2015), “A global perspective on diversity and inclusion in work organizations", International Journal of Human Resource Management, Vol. 26 No. 6, pp. 677-687.

Froese, F.J., Jommersbach, S., Klautsch, E. (2013), “Cosmopolitan career choices: A cross-cultural study of job candidates' expatriation willingness," International Journal of Human Resource Management. Vol. 24, pp. 3247-3261.

Froese, F.J., Kim, K., Eng, A. (2016), “Language, cultural intelligence, and inpatriate turnover intentions: Leveraging values in multinational corporations through inpatriates“, Management International Review. Vol. 56, pp. 283-301.

Froese, F.J., Stoermer, S., Reiche, B.S. and Klar, S. (2021), "Best of both worlds: how embeddedness fit in the host unit and headquarters improve repatriate knowledge transfer", Journal of International Business Studies, Vol. 52 No. 7, pp. 1331-1349.

Fulk, J. and Yuan, Y. C. (2013), "Location, motivation, and social capitalization via enterprise social networking”, Journal of Computer-Mediated Communication, Vol. 19 No. 1, pp. 20-37. Furumo, K. (2009), “The impact of conflict and conflict management style on deadbeats and deserters in virtual teams", Journal of Computer Information Systems, Vol. 49 No. 4, pp. 66-73. George, M. L. (2020), "Effective teaching and examination strategies for undergraduate learning during COVID-19 school restrictions", Journal of Educational Technology Systems, Vol. 49 No. 1, pp. $23-48$.

Golan, O. and Martini, M. (2019), “Religious live-streaming: constructing the authentic in real time", Information, Communication \& Society, Vol. 22 No. 3, pp. 437-454. 
Gong, Y. (2003), “Toward a dynamic process model of staffing composition and subsidiary outcomes in multinational enterprises", Journal of Management, Vol. 29 No. 2, pp. 259-280. Hjálmsdóttir, A., and V.S. Bjarnadóttir, V. (2021). "I have turned into a foreman here at home":Families and work-life balance in times of COVID-19 in a gender equality paradise. Gender, Work \& Organization, 28(1), pp. 268-283.

Han, S. J. and M. Beyerlein (2016), "Framing the effects of multinational cultural diversity on virtual team processes”, Small Group Research, Vol. 47, No (4), pp. 351-383.

Harrison, D. A., Shaffer, M. A. and Bhaskar-Shrinivas, P. (2004), "Going places: roads more and less travelled in research on expatriate experiences", in Martocchio, J. J. (Ed.), Research in Personnel and Human Resources Management, Vol. 23, Elsevier, Amsterdam, pp. 199-247. Harzing, A.-W., Pudelko, M. and Reiche, B.S. (2016), “The bridging role of expatriates and inpatriates in knowledge transfer in multinational corporations", Human Resource Management, Vol. 55 No. 4, pp. 679-695.

Haslberger, A. and Vaiman, V. (2013), "Self-initiated expatriates: a neglected source of the global talent flow”, in Vaiman, V. and Haslberger, A. (Eds.), Talent Management of Self-Initiated Expatriates: A Neglected Source of Global Talent, Palgrave Macmillan, Hampshire, pp. 1-18. Hocking, J. B., Brown, M. and Harzing, A. W. (2004), “A knowledge transfer perspective of strategic assignment purposes and their path-dependent outcomes", International Journal of Human Resource Management, Vol. 15 No. 3, pp. 565-586.

$\mathrm{Hu}, \mathrm{Y}$. (2015), "Health communication research in the digital age: a systematic review", Journal of Communication in Healthcare, Vol. 8 No. 4, pp. 260-288.

Jimenez, A., Boehe, D. M., Taras, V. and Caprar, D. V. (2017), “Working across boundaries: Current and future perspectives on global virtual teams", Journal of International Management, Vol. 23 No. 4, pp. 341-349. 
Jooss, S. McDonnell, A. and Conroy, K. (2021), "Flexible global working arrangements: An integrative review and future research agenda", Human Resource Management Review, Vol. 31, 100780.

Kim, H., Reiche, B.S. and Harzing, A.-W. (forthcoming), "How does successive inpatriation contribute to subsidiary capability building and subsidiary evolution? A longitudinal perspective on inpatriates' knowledge transfer", Journal of International Business Studies.

Kirkman, B. L., B. Rosen, C. B. Gibson, P. E. Tesluk and S. O. McPherson (2002), "Five challenges to virtual team success: Lessons from Sabre, Inc”, Academy of Management Perspectives, Vol. 16, No (3), pp. 67-79.

Klein, P., Ivanjek, L., Dahlkemper, M. N., Jeličić, K., Geyer, M. A., Küchemann, S. and Susac, A. (2021), "Studying physics during the COVID-19 pandemic: student assessments of learning achievement, perceived effectiveness of online recitations, and online laboratories", Physical Review Physics Education Research, Vol. 17 No. 1, 010117(11).

Kniffin, K. M., J. Narayanan, F. Anseel, J. Antonakis and S. P. Ashford (2021), “COVID-19 and the workplace: Implications, issues, and insights for future research and action", American Psychologist, Vol. 76, No (1), pp. 63-77.

Konradt, U., Hertel, G., \& Schmook, R. (2003), "Quality of management by objectives, task-related stressors, and non-task-related stressors as predictors of stress and job satisfaction among teleworkers". European Journal of Work and Organizational Psychology, Vol 12 No. 1, pp. 61-79. Lauring, J., R. Drogendijk and A. Kubovcikova (forthcoming), “The role of context in overcoming distance-related problems in global virtual teams: An organizational discontinuity theory perspective", International Journal of Human Resource Management. 
Lee, H.-J., Yoshikawa, K. and Harzing, A.-W. (2021), "Cultures and institutions: Dispositional and contextual explanations for country-of-origin effects in MNC 'ethnocentric' staffing practices”, Organization Studies, doi: 10.1177/01708406211006247

Mäkelä, Liisa, and Ulla Kinnunen (2018). "International business travelers' psychological wellbeing: the role of supportive HR practices."The International Journal of Human Resource Management 29, no. 7 (2018): 1285-1306.

Mäkelä, L., Saarenpää, K. and McNulty, Y. (2017), “International business travellers, short-term assignees, and international commuters", in McNulty, Y. and Selmer, J. (Eds), The Research Handbook of Expatriates, Edward Elgar, London, pp. 276-294.

Mayerhofer, H., Hartmann, L. C., and Herbert, A. (2004a), “Career management issues for flexpatriate international staff', Thunderbird International Business Review, Vol. 46 No. 6, pp. 647666.

Mayerhofer, H., Hartmann, L. C., Michelitsch-Riedl, G. and Kollinger, I. (2004b), "Flexpatriate assignments: a neglected issue in global staffing", International Journal of Human Resource Management, Vol. 15 No. 8, pp. 1371-1389.

Maznevski, M.L. and Chudoba, K.M. (2000), "Bridging space over time: global virtual team dynamics and effectiveness", Organization Science, Vol. 11, pp., 473- 492.

Moeller, M. and Reiche, B.S. (2017), “Inpatriates: a review, synthesis and outlook of two decades of research", in McNulty, Y. and Selmer, J. (Eds), The Research Handbook of Expatriates, Edward Elgar, London, pp. 218-240.

Mortensen, M. and P. J. Hinds (2001), “Conflict and shared identity in geographically distributed teams”, International Journal of Conflict Management, Vol. 12, No (3), pp. 212-238. 
Näsholm, M. H. (2014), “A comparison of intra-and inter-organizational global careers: repeat expatriates' and international itinerants' subjective experiences”, Journal of Global Mobility, Vol. 2 No. 2, pp. 183-202.

McNulty, Y. and Brewster, C. (2017a), “Theorising the meaning(s) of 'expatriate': Establishing boundary conditions for business expatriates", International Journal of Human Resource Management, Vol. 28 No. 1, pp. 27-61.

McNulty, Y. and Brewster, C. (2017b), "The concept of business expatriates”, in McNulty, Y. and Selmer, J. (Eds), The Research Handbook of Expatriates, Edward Elgar, London, pp. 21-60. Nell, P. C., N. J. Foss, P. G. Klein and J. Schmitt (2020), “Avoiding digitalization traps: Tools for top managers", Business Horizons, Vol. 64, No (2), pp. 163-169.

Nurmi, N. (2011), “Coping with coping strategies: How distributed teams and their members deal with the stress of distance, time zones and culture", Stress and Health, Vol. 27, No (2), pp. 123-143. Parish, H. (2020), “The absence of presence and the presence of absence: social distancing, sacraments, and the virtual religious community during the COVID-19 pandemic", Religions, Vol. 11 No. 6, pp. 276.

Peimani, N. and Kamalipour, H. (2021), "Online education and the COVID-19 outbreak: a case study of online teaching during lockdown”, Education Sciences, Vol. 11 No. 2, pp. 72. Piccoli, G., Powell, A. and Ives, B. (2004), "Virtual teams: team control structure, work processes, and team effectiveness", Information Technology \& People, Vol. 17 No. 4, pp. 359-379. Putri, A. and A. Amran (2021). “Employees’ Work-Life Balance Reviewed From Work And Home Aspect During COVID-19 Pandemic.” International Journal of Management Science and Information Technology, 1(1), pp. 30-34.

Przywara, B., Adamski, A., Kiciński, A., Szewczyk, M. and Jupowicz-Ginalska, A. (2021), “Online live-stream broadcasting of the holy mass during the COVID-19 pandemic in Poland as an example 
of the mediatisation of religion: empirical studies in the field of mass media studies and pastoral theology", Religions, Vol. 12 No. 4, pp. 261.

Raj, T. and Bajaj, A. (2021), "Living alone in lockdown: impact on mental health and coping mechanisms among young working adults. Current Psychology, 1-13.

Renshaw, P., Parry, E. and Dickmann, M. (2021). “The organisational value of international assignments: the relational underpinning”, The International Journal of Human Resource Management, Vol 32 (1): 106 - 146.

Reiche, B. S. (2011), “Knowledge transfer in multinationals: The role of inpatriates' boundary spanning”, Human Resource Management, Vol. 50 No. 3, pp. 365-389.

Reiche, B.S., Harzing, A.-W. and Kraimer, M.L. (2009), “The role of international assignees’ social capital in creating intellectual capital: A cross-level model", Journal of International Business Studies, Vol. 40 No. 3, pp. 509-526.

Reichl, P., Löw, C., Schröder, S., Schmidt, T., Schatzl, B., Lushaj, V., Hödl, O., Güldenpfennig, F. and Widauer, C. (2016), “The Salome experience: opera live streaming and beyond”, in Proceedings of the 2016 CHI Conference Extended Abstracts on Human Factors in Computing Systems, pp. 728-737.

Reinares-Lara, E., Martín-Santana, J. D. and Muela-Molina, C. (2016), “The effects of accent, differentiation, and stigmatization on spokesperson credibility in radio advertising", Journal of Global Marketing, Vol. 29 No. 1, pp. 15-28.

Richter, N. F., J. Martin, S. V. Hansen and V. Taras (2021), "Motivational configurations of cultural intelligence, social integration, and performance in global virtual teams", Journal of Business Research, Vol. 129, No (1), pp. 351-367.

Selmer, J. (2004), “Expatriates' hesitation and the localization of Western business operations in China”, International Journal of Human Resource Management, Vol. 15 No. 6, pp. 1094-1107. 
Selmer, J. (2021), “Editorial: virtual global mobility (VGM) - from pandemic necessity to competitive advantage”, Journal of Global Mobility, Vol. 9 No. 1, pp. 2-4.

Shankar, K. (2020). The impact of COVID-19 on IT services industry-expected transformations. British Journal of Management, 31(3), $450-452$.

Shaffer, M. A., Kraimer, M. L., Chen, Y. P. and Bolino, M. C. (2012), “Choices, challenges, and career consequences of global work experiences: a review and future agenda", Journal of Management, Vol. 38 No. 4, pp. 1282-1327.

Skulmowski, A. and Rey, G. D. (2020), "COVID-19 as an accelerator for digitalization at a German university: establishing hybrid campuses in times of crisis", Human Behavior and Emerging Technologies, Vol. 2 No. 3, pp. 212-216.

Stahl, G. K., Maznevski, M. L., Voigt, A. and Jonsen, K. (2010), "Unraveling the effects of cultural diversity in teams: a meta-analysis of research on multicultural work groups", Journal of International Business Studies, Vol. 41 No. 4, pp. 690-709.

Stoermer, S., Davies, S., Froese, F.J. (2021), “The influence of expatriates' cultural intelligence on embeddedness and knowledge sharing: The moderating effects of host country context", Journal of International Business Studies, Vol. 52 No. 3, pp. 432-453

Tharenou, P. and Caulfield, N. (2010), "Will I stay or will I go? Explaining repatriation by selfinitiated expatriates", Academy of Management Journal, Vol. 53 No. 5, pp. 1009-1028.

Welch, D. E., Welch, L. S. and Worm, V. (2007), “The international business traveller: a neglected but strategic human resource", International Journal of Human Resource Management, Vol. 18, pp. 173-183.

Westman, M. (2004), "Strategies for coping with business trips: a qualitative exploratory study", International Journal of Stress Management, Vol. 11, pp. 167-176. 
Table 1: Global Work Assignments and VGM Implications (adapted from Shaffer et al., 2012).

\begin{tabular}{|c|c|c|}
\hline Assignment Types & Categories & VGM Implications \\
\hline \multirow[t]{2}{*}{ Expatriates } & $\begin{array}{l}\text {-Corporate Expatriates } \\
\text { Employees working for business } \\
\text { organizations, who are sent overseas on a } \\
\text { temporary basis to complete a time-based } \\
\text { task or accomplish an organizational goal }\end{array}$ & $\begin{array}{l}\text { Possibly more (long-term) Corporate } \\
\text { Expatriates to } \\
\text {-Avoid or lessen the damaging influence of } \\
\text { cultural diversity in virtual work. } \\
\text {-Act in a bridging role between headquarters } \\
\text { and host country national employees, although } \\
\text { with some limitations to their bridging role }\end{array}$ \\
\hline & $\begin{array}{l}\text {-Self-Initiated Expatriates } \\
\text { Individuals who initiate and usually finance } \\
\text { their own expatriation and are not } \\
\text { transferred by organizations. They relocate } \\
\text { to a country of their choice to pursue } \\
\text { cultural, personal, and career development } \\
\text { experiences, often with no definite time } \\
\text { frame in mind }\end{array}$ & $\begin{array}{l}\text { Fewer foreign Self-Initiated Expatriates in top } \\
\text { positions abroad } \\
\text {-As leaders and decision makers, Self-Initiated } \\
\text { Expatriates may worsen the damaging } \\
\text { influences of cultural diversity in virtual work. } \\
\text {-Less familiarity with corporate policy and } \\
\text { therefore less versatility than Corporate } \\
\text { Expatriates }\end{array}$ \\
\hline \multirow[t]{4}{*}{ Global Travellers } & $\begin{array}{l}\text {-Short-Term Assignees } \\
\text { Employees on international assignments that } \\
\text { are longer than business trips yet shorter } \\
\text { than typical corporate expatriate } \\
\text { assignments; usually less than one year }\end{array}$ & $\begin{array}{l}\text { Somewhat fewer Short-Term Assignees } \\
\text {-Some of their assignments will be replaced } \\
\text { by VGM via experts/specialists }\end{array}$ \\
\hline & $\begin{array}{l}\text {-Flexpatriates } \\
\text { Employees who travel for brief assignments, } \\
\text { away from their home base and across } \\
\text { cultural or national borders, leaving their } \\
\text { family and personal life behind }\end{array}$ & $\begin{array}{l}\text { Fewer Flexpatriates } \\
\text {-Some of their travels will be replaced by } \\
\text { VGM via experts and specialists }\end{array}$ \\
\hline & $\begin{array}{l}\text {-International Business Travellers } \\
\text { Employees who take multiple short } \\
\text { international business trips to various } \\
\text { locations without accompanying family } \\
\text { members }\end{array}$ & $\begin{array}{l}\text { Much fewer International Business Travellers } \\
\text {-Most of their travels will be replaced by } \\
\text { VGM via experts and specialists }\end{array}$ \\
\hline & $\begin{array}{l}\text {-International Commuters } \\
\text { Employees who reside (with their families) } \\
\text { in one country and travel to another country } \\
\text { to work, with commutes occurring on a } \\
\text { daily, weekly, or another time interval basis. }\end{array}$ & $\begin{array}{l}\text { Much fewer International Commuters } \\
\text {-at least in terms of physical mobility } \\
\text {-VGM may increase the number of employees } \\
\text { who commute virtually }\end{array}$ \\
\hline
\end{tabular}

